\title{
PENGARUH FAKTOR BIOEKOLOGIS TERHADAP DISTRIBUSI JERUK KEPROK MAGA MANDAILING NATAL
}

\author{
Muhammad Ihsan $^{1)}$, Hapsah Delila' ${ }^{1)}$, Mawarni' ${ }^{1)}$, Jalilah Azizah Lubis ${ }^{1)}$ \\ 1) Fakultas Keguruan dan Ilmu Pendidikan Universitas Muhammadiyah Tapanuli Selatan \\ e-mail:jalilah.azizah@um-tapsel.ac.id
}

\begin{abstract}
Maga Tangerine Orange is one of the many citrus varieties in the Balitbangtan genetic resource garden. Maga Tangerine is still a garden plant in its area of origin in Puncak Sorik Marapi District, Mandailing Natal District. This type of orange has the advantage of sweet fruit flavor, rounded sprawl shape, soft and easy to peel. But the CVPD virus caused a large number of deaths in the past 10 years, which caused the tangerine orange farmers to plant cacao at North Sumatra's Mandailing Natal. This study aims to determine the effect of bioecological factors on the spread of tangerine maga Mandailing Natal. This research was conducted from March to July 2019 at Mandailing Natal and at the Biology Laboratory of Muhammadiyah University in South Tapanuli. This study uses descriptive research methods. The results of the study showed that citrus keprok maga plants grew with temperatures of 27.9oC - 31oC, air humidity 54\% -82\%, rainfall 1004,628 Hpa-1008,466 Hpa, soil pH 5,3-6,4 with organic content contained between $12.7 \%-18.9 \%$, as well as the content of manganese and lime which only slightly later the soil wetness level of $15 \%-20 \%$ and clayy and sandy soil texture.
\end{abstract}

Keywords: Maga Tangerine Orange, Bioecologist, Distribution

\begin{abstract}
Abstrak
Jeruk Keprok Maga merupakan salah satu dari sekian banyak varietas jeruk yang ada di kebun sumber daya genetik Balitbangtan. Jeruk Keprok Maga sampai saat ini masih merupakan tanaman pekarangan di daerah asalnya di Kecamatan Puncak Sorik Marapi Kabupaten Mandailing Natal. Jeruk jenis ini mempunyai keunggulan rasa buah yang manis, bentuk buah bulat gepeng, lembut dan mudah dikupas. Tetapi virus CVPD menyebabkan kematian dalam jumlah yang besar pada 10 tahun yang lalu sehingga menyebabkan petani jeruk keprok maga beralih menanam kakao di Mandailing Natal Sumatra Utara. Penelitian ini bertujuan untuk mengetahui pengaruh faktor bioekologis terhadap penyebaran jeruk keprok maga Mandailing Natal. Penelitian ini dilaksanakan dari bulan Maret sampai bulan Juli 2019 di Mandailing Natal dan di Laboratorium Biologi Universitas Muhammadiyah Tapanuli Selatan. Penelitian ini menggunakan metode penelitian deskriptif. Hasil penelitian menunjukkan bahwa tanaman jeruk keprok maga tumbuh dengan temperatur $27,9^{\circ} \mathrm{C}-31^{\circ} \mathrm{C}$, kelembapan udara $54 \%-82 \%$, curah hujan 1004,628 Hpa-1008,466 Hpa, pH tanah 5,3-6,4 dengan kadar organic yang terkandung antara 12,7\%-18,9\%, serta kandungan mangan dan kapur yang hanya sedikit kemudian tingkat kebasahan tanah 15\%-20\% dan tekstur tanah yang liat dan berpasir.
\end{abstract}

Kata Kunci : Jeruk Keprok Maga, Bioekologis, Distribusi

\section{PENDAHULUAN}

Jeruk Keprok Maga merupakan salah satu komoditi buah buahan andalan Sumatera Utara, karena mempunyai keunggulan komperatif dan kompetitif dengan kultivar atau varietas jeruk lainnya, yaitu penampilannya yang menarik dan rasanya yang manis dan aroma 
yang kuat serta daerah pemasarannya yang luas, selain Sumatera Utara juga daerah Sumatera Barat, Riau, Jakarta bahkan ekspor ke Singapura. Jeruk keprok maga merupakan salah satu dari varietas jeruk yang belum banyak dikenal dan belum di kembangkan secara luas. Jeruk Keprok Maga merupakan salah satu dari sekian banyak varietas jeruk yang ada di kebun sumber daya genetik Balitbangtan. Jeruk Keprok Maga sampai saat ini masih merupakan tanaman pekarangan di daerah asalnya di Kecamatan Puncak Sorik Marapi Kabupaten Mandailing-Natal. Berdasarkan SK Pelepasan varietas No 216/kpts/TP.240/4/2001, jeruk jenis ini mempunyai keunggulan rasa buah yang manis, bentuk buah bulat gepeng, lembut dan mudah dikupas.

Keunggulan lain jeruk ini adalah penampilan buah yang menarik dengan warna kulit buah dan daging buah oranye. Selain itu mempunyai tekstur daging buah yang halus dan berhujan. Produktivitas jeruk ini juga cukup tinggi yaitu bisa mencapai 200 kg/pohon/tahun. Wilayah adaptasi jeruk ini berada di ketinggian 600 - 800 mdpl. Melihat keunggulannya, jeruk ini sangat berpotensi untuk dikembangkan. Jeruk ini digemari oleh masyarakat dan mempunyai nilai ekonomis yang tinggi.

Produktifitas Jeruk Keprok Maga di Kabupaten Mandailing Natal sangat jauh mengalami penurunan bahkan untuk pasar tradisional daerah setempat tidak mampu memenuhi permintaan konsumen. Sulit menemukan keberadaan Jeruk Keprok Maga, bagi konsumen yang berniat mengkonsumsi jauh jauh hari sudah memesan terlebih dahulu kepada pemilik pohon.

Penyebaran Jeruk Keprok Maga ditemukan pada dataran tinggi. Pola penyebaran merupakan salah salah satu ciri khas dari setiap organisme di suatu habitat. Pola penyebaran tergantung pada faktor lingkungan maupun keistimewaan biologis organisme itu sendiri. Organisme dalam populasi dapat tersebar dalam bentuk bentuk umum yang terdiri dari tiga macam yaitu penyebaran secara acak, merata dan berkelompok (Indriyanto, 2008). Informasi mengenai penyebaran sangat penting karena hal tersebut berperan dalam pengelompokkan individu yang ditemukan dalam populasi. Selain itu pola penyebaran berhubungan pula dengan faktor bioekologi yang memberikan pengaruh pada individu yang di teliti.

\section{METODE}

Penelitian ini dilaksanakan di Kecamatan Puncak Sorik Marapi Kabupaten Mandailing Natal Sumatera Utara. Waktu penelitian ini direncanakan selama empat bulan. Alat dan bahan yang digunakan pada penelitian ini yaitu alat tulis, kertas $\mathrm{pH}$, termohygrometer, penggaris, thermometer, neraca analitik, cawan keramik, hujan, oven, botol aqua gelas, dan tanah. Metode penelitian yang digunakan adalah metode survey.

Penelitian ini terdiri dari dua bagian, yaitu prosedur kerja pengukuran faktor iklim (iklim mikro) serta pengukuran faktor fisika dan kimia tanah. Prosedur kerja penelitian pada pengukuran faktor iklim yaitu dilakukan pengukuran temperature udara dan kelembaban relatif udara menggunakan termohygrometer pada ketinggian 1 dan 2 meter dari permukaan tanah masing- masing selama 5 menit.

Pada pengukuran faktor fisika dan kimia tanah yaitu dilakukan pengukuran suhu pada permukaan tanah dan pada kedalaman $30 \mathrm{~cm}$ dengan bantuan alat ukur thermometer $\mathrm{Hg}$. Diukur $\mathrm{pH}$ tanah dengan menggunakan soil tester. Pengukuran kelembaban tanah diukur dengan menghitung curah hujan tanah/KAT dengan cara pengeringan. Kemudian diambil dua sampel tanah terbuka dan ternaung. Ditimbang sampel tanah sebanyak 2 gr kemudian dikeringkan di dalam oven pada suhu 105 0C selama 2 hari, lalu berat tanah tersebut ditimbang. Diukur curah organik tanah (KOT) dengan cara membakar 5 gram tanah yang telah dikeringkan di suhu $105{ }^{\circ} \mathrm{C}$ selama 2 hari, lalu berat tanah tersebut ditimbang.Data yang dihasilkan akan di analisis secara deskriptif. 


\section{HASIL DAN PEMBAHASAN}

Jeruk keprok maga merupakan salah satu komoditi buah buahan andalan sumatera utara, karena mempunyai keunggulan komperatif dan kompetitif dengan varietas jeruk lainnya, yaitu penampilannya yang menarik, rasa yang manis dan aroma yang kuat serta pemasaran yang sangat luas. Bagi konsumen yang berniat mengonsumsinya, jauh-jauh hari sudah harus memesan terlebih dahulu kepada pemilik pohon, dikarenakan jumlah pokok dan buahnya yang kurang dan sulit untuk menemukannya serta peminatnya dari tahun ke tahun terus mangalami peningkatan. Dengan melakukan penelitian di tiga daerah dan 3 titik sampel berbeda yang masih berada di daerah puncak sorik marapi, didapatkan data hasil uji bioekologis yang dapat dilihat pada tabel 1 .

Tabel 1. Hasil Uji Bioekologis Daerah Yang Ditanami Jeruk Keprok Mag
\begin{tabular}{|c|l|l|}
\hline No & \multicolumn{1}{|c|}{ Faktor Pengamatan } & \multicolumn{1}{c|}{ Keterangan } \\
\hline 1 & Temperatur & $27,9{ }^{0} \mathrm{C}-31^{0} \mathrm{C}$ \\
\hline 2 & Kelembaban Tanah & $54 \%-82 \%$ \\
\hline 3 & Curah hujan & $1004,628 \mathrm{Hpa}-1008,466 \mathrm{Hpa}$ \\
\hline 4 & pH Tanah & $5,3-6,4$ \\
\hline 5 & Kadar Bahan Organik Tanah & $12,7 \%-18,9 \%$ \\
\hline 6 & Kandungan Mn & Sedikit \\
\hline 7 & Kandungan Kapur & Sedikit \\
\hline 8 & Tingkat Kebasahan Tanah & $15 \%-20 \%$ \\
\hline 9 & Tekstur tanah & Liat berpasir \\
\hline
\end{tabular}

Sedangkan untuk penentuan mangan di lakukan dengan cara meneteskan $\mathrm{H}_{2} \mathrm{O}_{2} 10 \%$ dengan cara mengamati percikan saat meneteskan larutan pada masing-masing sampel, dan hasil yang di dapatkan bahwa dari ketiga sampel hanya mengandung mangan yang sedikit. Penentuan kapur di lakukan dengan cara meneteskan $\mathrm{HCL}_{2} \mathrm{~N} 10 \%$ dengan cara mendengar desisan saat meneteskan larutan pada masing-masing sampel, dan hasil yang didapatkan bahwa dari ketiga sampel hanya mengandung kapur yang sedikit Penentuan tingkat kebasahan tanah di lakukan dengan metode remas, gravimetric dan pengovenan, dari ketiga sampel di dapatkan hasil bahwa ketiga sampel tingkat kebasahannya antara $15 \%$ - $20 \%$. Tekstur tanah yang dapat di tumbuhi jeruk keprok maga yaitu tanah liat dan berpasir.

Dari data pada tabel 1. di dapatkan hasil bahwa temperatur yang bagus untuk jeruk keprok maga berada pada $27,9{ }^{0} \mathrm{C}-31{ }^{0} \mathrm{C}$, karena pada temperatur inilah jeruk bisa tumbuh dengan baik, kelembapan udara 54\% - 82\% pada kelembapan ini jeruk dapat tumbuh nyaman dan berbuah dengan bagus, Menurut Lee dan Kader (2000) perubahan temperatur udara sangat berperan terhadap aktivasi energi maupun inaktivasi enzim. Temperatur yang terlalu tinggi akan meningkatkan penggunaan energy hasil fotosintesis, sehingga hasil netto yang disimpan sebagai cadangan makanan pada berbagai organ tanaman menurun. Dengan adanya temperature yang sesuai hal ini menyebabkan buah dapat berkembang dan tidak terjadi pengisutan pada buah serta curah hujannya mencapai 1004,628 Нpa - 1008, 466 Нpa, curah hujan yang tinggi dapat menyebabkan cadangan makanan tumbuhan tercukupi dan buah dapat disimpan dalam jangka waktu yang lama, comportable 20-30. Sebagaimana dalam Bordeala et al. (2002) dilihat dari pendapat masyarakat untuk menyatakan bahwa kualitas jeruk bagus dapat dilihat dari beberapa faktor antara lain adalah rasa, kenampakan, ketegasan warna, tekstur, kandungan nutrisi, maupun konsentrasi larutan yang terkandung di dalamnya.

Pada data tersebut ketiga titik sampel $\mathrm{pH}$ tanah antara 5,3 - 6,4, dalam ilmu pertanian pengaruh terhadap $\mathrm{pH}$ tanah sangat memiliki peranan yang sangat penting gunanya untuk menentukan mudah tidaknya ion-ion unsur hara di serap oleh tanaman. Menurut Bangun (2009) 
dalam Purnomosidhi, et al (2007) Pada umumnya unsur hara akan mudah di serap oleh tanaman pada $\mathrm{pH}$ 6-7, karena pada $\mathrm{pH}$ tersebut sebagian besar unsur hara akan mudah larut. Temperatur optimal untuk pertumbuhan jeruk yaitu anara $25^{\circ} \mathrm{C}$ dan $30^{\circ} \mathrm{C}$. Apabila temperature diatas $38^{\circ} \mathrm{C}$ kemungkinan pertumbuhannya akan terhenti. Berdasarkan dari ketiga titik sampel suhu pada lokasi tersebut antara $27,9{ }^{\circ} \mathrm{C}-31^{\circ} \mathrm{C}$. Menurut aktivitas pertumbuhan jeruk akan sangat kurang bila temperature kurang dari $13^{\circ} \mathrm{C}$ tetapi masih bisa bertahan pada temperature lebih dari $38^{0} \mathrm{C}$.

Pada penentuan bahan organik tanah dari ketiga titik sampel kadar bahan organic yang terkandung antara 12,7\% - 18,9\%. Kemudian pada penentuan Mn (mangan) ke tiga titik sampel tersebut di amati bahwa saat penenesan $\mathrm{H}_{2} \mathrm{O}_{2} 10 \%$ telihat adanya percikan, namun pada penetesan di amati juga tidak terdapat buih di atas tanah ini menunjukkan bahwa pada sampel tidak terdapat kandungan Mangan. Kekurangan Mangan dapat menyebabkan pertumbuhan tanaman yang tidak normal. Hal tersebut dapat di atasi dengan pemupukan tanah dan daun. Pada penentuan tingkat kebasahan tanah kami melakukan peremasan dan pengopenan, yang hasilnya tekstur tanah lembut, berpasir, dan tidak keras, sedangkan hasil yang di open tanah mengalami penurunan berat, ini membuktikan bahwa tanah berada dalam tingkat kebasahan yang normal, hal ini sangat baik untuk perakaran tumbuhan dan juga buah karena akan menghasilkan buah yang mengandung hujan dengan stabil.

Penentuan kapur pada tanah di lakukan dengan cara penetesan $\mathrm{HCL}_{2} \mathrm{~N} 10 \%$, dan hasilnya pada ketiga titik sampel terdengar bunyi desisan, ini menunjukkan bahwa kandungan kapur pada tanah sedikit sekali. Karena jika semakin banyak kandungan kapur maka basa yang terkandung dalam tanah akan semakin besar. Sedangkan tanah yang mengandung basa dikategorikan tanah yang tidak subur dan tidak mengandung Fe.

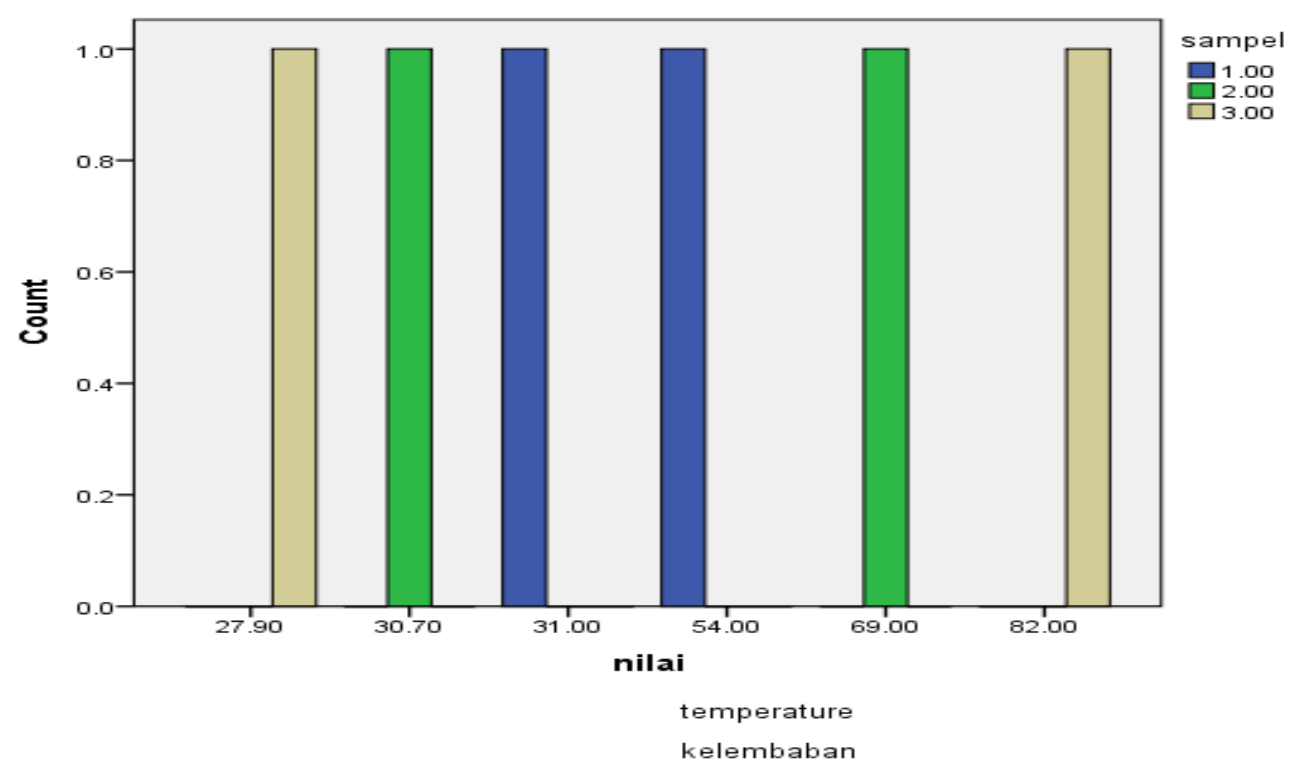

Gambar 1. Grafik Temperatur dan Kelembaban Lingkungan

Dari gambar 1. didapatkan bahwa dalam penanaman jeruk lingkungan yang baik digunakan pada daerah puncak sorik marapi dimana temperature dan kelembaban udara yang memiliki jarak yang lebih dekat dan $\mathrm{pH}$ tanah terlihat normal. Rayes (2006) menyatakan lingkungan yang lebih spesifik pada tanaman adanya kesesuaian lahan tersebut ditinjau dari sifat fisik lingkungannya, yang terdiri dari iklim, tanah, topografi, hidrologi dan drainase yang sesuai untuk usaha tani atau komoditis tertentu yang produktif. 


\section{KESIMPULAN}

Dari hasil dapat diambil kesimpulan bahwa : Jeruk keprok maga merupakan tanaman komoditi khas sumatera utara, memiliki rasa dan aroma yang khas, serta pemasaran dan peminatnya yang cukup luas dan banyak. Jeruk keprok maga dapat tumbuh bagus dengan temperatur tanah dari $27^{\circ} \mathrm{C}-31^{\circ} \mathrm{C}$, kelembapan udara 54\% - 84\%, Curah hujan 1004,628 $\mathrm{HPa}$ - 1008,466 Hpa, kenyamanan suhu pada proses metabolisme tubuh tumbuhan berkisar 20 - 30. Tekstur tanah liat, lembab, tidak keras, sedikit berpasir dan memiliki daya serap air yang tinggi. Jeruk keprok maga bagus tumbuh pada $\mathrm{pH}$ tanah antara 5,3 - 6,4. Bahan organic yang terkandung antara $12,7 \%-18,9 \%$.

\section{UCAPAN TERIMA KASIH}

Terimakasih kepada SIMBELMAWA -DIKTI yang telah memberikan hibah dana PKM - Penelitian dan kepada Universitas Muhammadiyah Tapanuli Selatan yang telah memberikan fasilitas pada penelitian ini.

\section{DAFTAR PUSTAKA}

Bangun, D.A. 2009. Kajian Beberapa Metode Perangkap Lalat Buah (Diptera : Tephritidae) Pada Pertanaman Jeruk Manis (Citrus auranticum L.) di Desa Sukanalu Kabupaten Karo.[Skripsi].Repository USU. Universitas Sumatera Utara. Medan

Bordeala, G., I. Myers-Smith, M. Midak, and A. Szeremeta. 2002. Food quality: a comparison of organic and conventional fruits and vegetables. Article-internet (http://www.kursus.kvl.dk/shares/ea/03Projects/32gamle/2002/FoodQualityFinal.pdf).

Indriyanto. 2008. Ekologi Hutan. Jakarta : Bumi Aksara

Lee, S.K. and A.A. Kader. 2000. Preharvest and postharvest factors influencing vitamin C content of horticultural crops. Postharvest Biology and Technology 20(3):207-220.

Odum, E.P. 1993. Dasar-Dasar Ekologi. Edisi Ketiga. Yogyakarta : Gajah Mada University Press.

Polunin, N. 1990. Pengantar Geografi Tumbuhan dan Beberapa Ilmu Serumpun. Yogyakarta Gadjah Mada : University Press

Rifa'i, Mien. A. 2004. Kamus Biologi. Cetakan ke-4. Jakarta : Balai Pustaka

Rayes M. L. 2006. Metode Inventarisasi Sumber Daya Lahan. Andi, Malang 